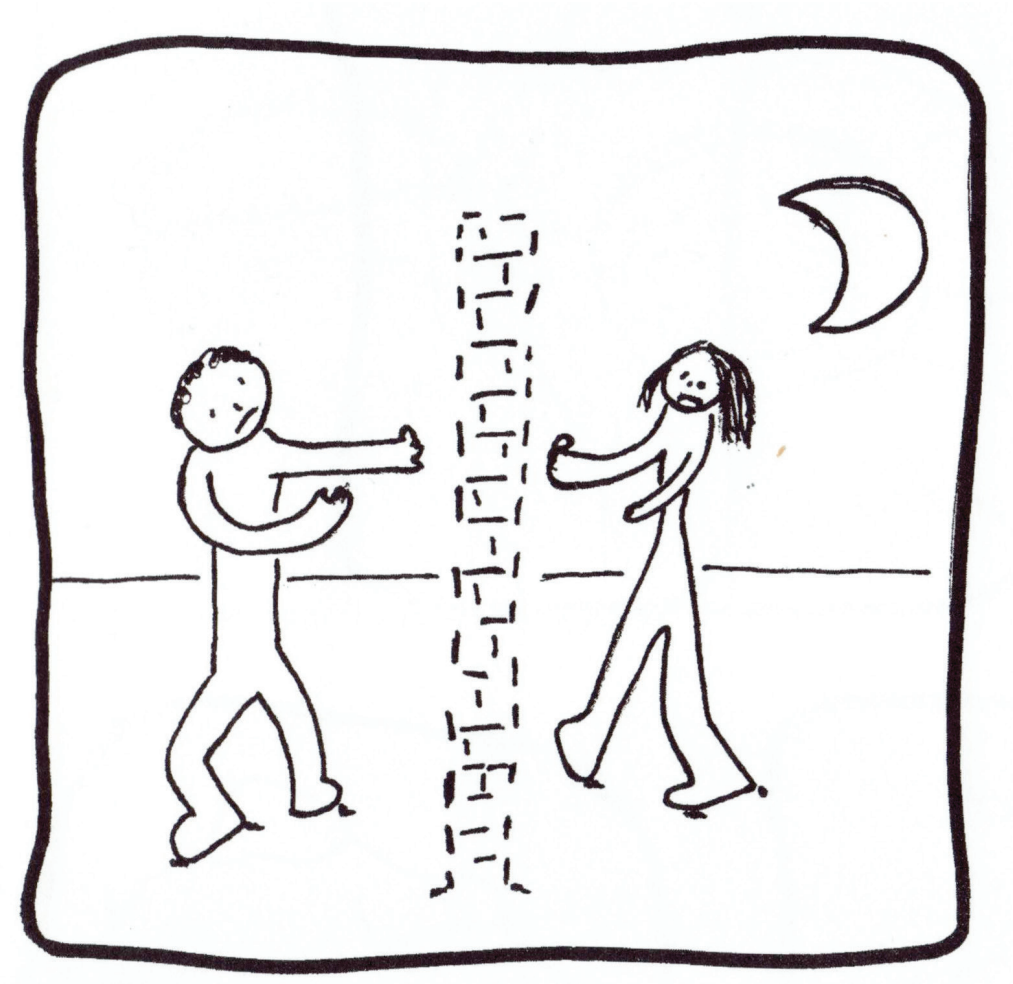

PA GRUUI AF HOJE,

US'UnCIGE MURVäruEA

KAN MENNESURR ALDRIG HELT KOMAE TiL AT MERUE HINA DEN 


\section{Jakob Schweppenhäuser}

\section{Vi er ikke robotter, hvis man kan sige det på den måde}

\section{Digressiv køretur gennem Nikolaj Zeuthens flerstrengede fejlbarlighedskunst}

\section{Indkørsel}

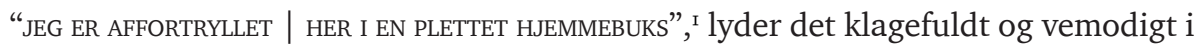
sangen "Sneen falder" fra albummet Bilerne kører (2008) af orkesteret Skammens Vogn, i hvilket Nikolaj Zeuthen optræder som tekstforfatter og forsanger. Imidlertid er det en påfaldende fortryllende affortryllethed, der iscenesættes her og generelt i det mangesidige zeuthenske virke: Den er formuleret med æstetisk prægnans og humor og knytter sig til den gennemgående fejlbarlighed, der i det følgende skal fungere som pejlemærke. Skammens Vogn kører ad hullede veje, det rasler i hængslerne, den vækker pinlig opsigt i trafikken. I en sky af flovhed, kejtethed og mislykkethed er det lykkedes Zeuthen at etablere et originalt kunstnerisk udtryk, femfoldigt manifesteret som sang, digt, roman, drama og tegneserie, som det er værd at kaste et nærmere blik på - og ikke mindst: at rette høresansen mod. Hovedvægten er her lagt på den del af udtrykket, som er blevet til inden for rammerne af Skammens Vogn, da denne er den sparsomst beskrevne, men ikke uden at skæve til siderne.

Et livtag med Zeuthen og Skammens Vogn er også et livtag med et felt: med sangteksten generelt og specifikt med den nye danske litterært interessante af slagsen. Sangteksten fører, som bl.a. litteraten m.m. Guido Naschert (2006) og medieteoretikeren Sibylle Moser (2007) har gjort opmærksom på, sin kolossale udbredelse til trods en uhyre beskeden tilværelse i den videnskabelige verden, også her til lands - men ikke i denne tekst.

\section{digter med lille d \& den lydlige vending}

I et interview med forfatteren Carsten René Nielsen ræsonnerer digteren Morten Søndergaard: "Jeg tror, at der er sket noget med digterrollen. Jeg tror, at for visse digtere er det blevet mindre vigtigt at være digter: Det er ikke digter med stort "D", og det gør ikke noget, at man laver alt muligt andet” (Nielsen 1996). Denne søndergaardske diagnose har snart 17 år på bagen og befatter sig med halvfemsergenera- 
tionen af danske digtere - den såkaldt encyklopædiske og verdensvendte. Imidlertid har diagnosen ikke mistet sin aktualitet: det, der skete med digterrollen i 90'erne, har fortsat gyldighed i dag, muligvis endda større gyldighed. Listen over digtere, der er debuteret efter halvfemserne, og som altså ikke tilhører halvfemsergenerationen, men alligevel "laver alt muligt andet" end at skrive digte, er omfattende. Der er blevet argumenteret overbevisende for, at man på den litterære scene de senere år har kunnet identificere en voksende lydlig vending (bl.a. Ringgaard 2000 og Rasmus Bo Sørensen 2009), og en betragtelig del af den nye generation af digtere - med lille d - har netop det til fælles, at (dele af) deres tværgående aktiviteter har med musik at gøre. Nogle få fremtrædende eksempler kunne være Lars Skinnebach, Kristian Leth, Claus Handberg, Lone Hørslev, Marius Nørup-Nielsen, Anders Søgaard - og Nikolaj Zeuthen.

Nikolaj Zeuthen statuerer et pragteksempel på denne nye digtertype, som "laver alt muligt andet": Digteren Zeuthen debuterede i 2009 med samlingen Oliebål, som i 2012 fulgtes op af Frivers fra Howitzvej, og senere i år udkommer Stråler. Akademikeren Zeuthen indleverede i 2009 sin ph.d.-afhandling Subjektivitet og betydningsstruktur i den litterære fiktion: Udkast til en fænomenologisk narratologi ved Københavns Universitet og havde derefter en post.doc.-ansættelse ved semiotik på Aarhus Universitet. Redaktøren Zeuthen udvalgte og redigerede i 2005 Fluxuskunstneren Knud Pedersens skrifter og sad fra 2007 til 2010 i litteraturtidsskriftet Den Blå Ports redaktion. Tegneserieforfatteren Zeuthen udgav i 2010 de 12 historier Hvad synes du om dansk litteratur? - samme år som romanforfatteren Zeuthen udsendte Verdensmestre - En historie fra 00'erne. Musikeren, sangeren og tekstforfatteren Zeuthen udsendte i 2007, som del af orkesteret Skammens Vogn, det selvbetitlede debutalbum, året efter pladen Bilerne kører, og i skrivende stund færdiggøres opus 3. De forskellige kunstneriske udtryk former et sammenhængende hele, der samtidig lader det enkelte medies specifikke egenskaber træde frem.

Zeuthens tekstunivers i Skammens Vogn (som foruden Zeuthen består af musikerne Jakob Millung og Oliver Hoiness) indskriver sig på den ene side i en dansk sangskrivertradition med valgslægtskaber som Kim Larsen, Anne Linnet og det tidlige Shu-bi-dua/Michael Bundesen (jf. fx Christiansen 2010, 69), på den anden side i en skriftlig dansk litteraturtradition, hvorfra især Dan Turèll og Per Højholts indflydelse kan spores, men også Vita Andersens socialrealistiske knækprosa er blevet nævnt (fx Mygind 2009). I det følgende lades yderligere litteratur- og rockhistoriske indplaceringer ude af syne, men disse inspiratorer, samt Zeuthens placering med et ben i hver tradition, afspejler et træk hos Skammens Vogn, som det er værd kort at fremhæve: dobbeltheden af bredt appellerende folkelighed og subtilt raffinement - og en tilsvarende dobbelthed af det naivt infantile og det komplekst elaborerede. Mere herom senere.

\section{Overhørt/underbelyst}

At ikke universitetslitterater og litteraturkritikere, men udelukkende musikanmeldere, hvis kernekompetence egentlig er en anden, har fors $\emptyset \mathrm{gt}$ at beskrive den lyrik, Nikolaj Zeuthen har foldet ud inden for rammerne af Skammens Vogn, skyldes i 
hvert fald tre omstændigheder: (i) teksterne er sungne, (ii) de er integreret i en musikalsk sammenhæng, og (iii) de er placeret inden for nogle andre kulturelle rammer end skønlitteraturen. Den første omstændighed angår spørgsmål vedrørende medialitet, den anden intermedialitet og den tredje kulturelle kredsløb. Imidlertid kan ingen af disse tre forhold retfærdiggøre underbelysningen, som ingenlunde begrænser sig til Skammens Vogn: Det samme gør sig gældende for eksempelvis Under Byen og Peter Sommers vedkommende, for blot at nævne to relevante navne. Imidlertid har heller ikke vægtige sangskrivere som C.V. Jørgensen og Peter A.G. fået en fyldestgørende litterær behandling. Ikke blot i det anglofone rum findes et "stort lydarkiv [...], som endnu ikke er blevet behandlet og fortolket seriøst" med avantgardedigteren og -teoretikeren Charles Bernstein (1998, 5). Ikke blot i det tysksprogede har nyere sangtekster "stadig ikke fundet adgang til lyrikhistorien, skønt lyrikken i sit udspring var sang" med Guido Naschert $(2006,106)$ : Begge dele er netop også tilfældet på dansk grund. Derfor nu et nærmere blik på de tre ovennævnte omstændigheder, som kan være medvirkende til sangtekstens vanskelige videnskabelige kår.

i. Det er ikke kutyme at beskæftige sig med sunget lyrik på litteraturstudierne eller i litteraturkritikken:² Skriftens medium er altdominerende. I første ombæring kan forklaringen findes i intermedialitetsteoretikeren Lars Elleströms helt enkle konstatering: "En 'normal' digtoplæsning betragtes som regel som litteratur, mens en syngende fremførelse af samme digt tæller som musik" (2012, 30). "Tæller som" svarer vel til, at sangen ubevidst hos flertallet kategoriseres som først og fremmest musik. ${ }^{3}$ Dertil kommer den omstændighed, at det simpelthen er vanskeligere at arbejde litteraturvidenskabeligt med sang end med skrift: Lyd som fænomen er grundlæggende vanskeligt at beskrive, ligesom den menneskelige stemmes måde at etablere betydning på, eksempelvis som den undersøges i musikvidenskabelige vokalitetsstudier, befinder sig et godt stykke uden for det klassiske lyrikanalytiske revir. Til trods for lyrikkens oprindelige forankring i mundtligheden og forbundethed med sangen, som Naschert just pegede på, har lyrikken over de seneste århundreder, groft sagt, bevæget sig i retning af en stadig større skriftlighedsorientering, hvorfor litteraturforskeren Frank Kjørup, i sin omfattende studie Sprog versus sprog, kan karakterisere "det moderne vers [som] indbegrebet af skriftlighed" $(2003,15)-\mathrm{i}$ "en moderne visuel virkelighed" (op. cit., 149). Men: denne digtningens skriftlighedstilstand er ikke absolut, og det hørbare vers har absolut ikke udspillet sin rolle. Man kan måske endda argumentere for, at det kun synlige digt blot er at betragte som en historisk parentes - men dén diskussion vil det føre for vidt at føre videre her. I stedet tilbage til litteraturstudiernes og -kritikkens negligering af den lydlige lyrik, som er problematisk af især to grunde: Dels har der fundet nogle også fra et litterært perspektiv særdeles interessante kunstneriske landvindinger sted inden for den lydlige poesi, dels har denne en massiv kvantitativ overvægt hos den brede befolkning. Mens, med Naschert, "den 'unge lyrik' fortrinsvis når en begrænset akademisk målgruppe" $(2006,106)$, er sang- og raptekstlytning, enten in- eller ekstensiv, en naturlig del af hverdagen for så godt som alle og enhver. Digtoplæsningslytning i mindre grad, men angiveligt stadig i højere grad end den stille, ensomme digtlæsning.

ii. Ikke nok med at sangteksten med sin mundtlighed altså volder mediale pro- 
blemer - beskæftigelsen med den kompliceres også yderligere af dens intermediale karakter: Den er knyttet til musik. Til trods for lyrikkens ikke blot historiske men også etymologiske forbindelse til musikken (over lyrikos, adjektivdannelsen til lyra, kan lyrik føres tilbage til lyre), synes kombinationen af de to kunstarter ikke at være et nærliggende anliggende for litterater: "Der er [...] en tendens hos litterater til at 'overhøre' musikken og dens betydning" (Engberg, Richard \& Svendsen 2004, 7), som Spring-redaktionen formulerer det i et temanummer om musik og litteratur. Selvsagt kan det være vanskeligt at begribe og udlægge nuancerne af den musikalsk-litterære betydningsdannelse på en fuldstændigt udtømmende måde uden en musikvidenskabelig baggrund, men mindre kan også gøre det - Naschert plæderer for et beskrivelsesniveau, som befinder sig mellem "den hårde musikvidenskabelige analyse og den rene intuition" $(2006,118)$. Med en betoning af, og en bevidsthed om, at indfaldsvinklen er primært litterær, kan analytikeren lade sig inspirere af musikvidenskabelige analyseredskaber og denne disciplins auditive sensibilitet. Det væsentlige er opmærksomheden på, at sangteksten udgør en del af et sammensat og mangefacetteret hele, udgør én dimension i et grundlæggende tværmedialt kunstværk, og at den således ikke bør behandles som et digt og ikke vurderes på et digtbaseret grundlag - "eftersom genren 'sang' må bedømmes efter egne målestokke. Sangtekster er nemlig ikke digte” (Naschert 2006, 108; i Schweppenhäuser 2011 findes en gennemgang af Nascherts forsøg på en kortlægning af de mest basale forskelle mellem sangtekster og digte).

iii. Også kulturelle omstændigheder, forbundet med ovenstående mediale og intermediale udfordringer, medvirker til den litteraturvidenskabelige negligering af feltet. Sunget og musikalsk forankret placerer sangteksten sig i andre kredsløb og smagsfællesskaber end dem, litterater almindeligvis fokuserer på. Vandfangetredaktionen formulerer sig konfrontatorisk over for 'etablissementet' i et nummer om sangtekstforfattere: "Vi lægger således fokus på den forsømte gruppe af poeter, som det litterære etablissement overser i deres ensidige fokus på 'finkultur"' (Søndergaard 2008, 4). Dertil lægger sig et andet aspekt; dette, nemlig, at der ikke nødvendigvis er sammenfald mellem det, der vinder stor udbredelse og det, der er af litterær interesse: broderparten af de sangtekster, der florerer på de store danske tv- og radiokanaler samt internetportaler, er ofte i højere grad relevante som analyseobjekter for kultur- og medievidenskabelige discipliner end for litteraturvidenskaben. Ligesom det fx er tilfældet med dansk rapmusik, er en stor del af de eksperimenterende, nyskabende og æstetisk interessante sangtekster forvist til mindre platforme. Den manglende udbredelse i massemedier betyder imidlertid ikke, at de dermed indoptages i de finkulturelle sammenhænge, litteraturvidenskaben oftest har blikket rettet mod (jf. Vandfanget), og påstanden skal her lyde, at problemet er, at mange litterater dermed slet ikke kommer i berøring med dem. Og hvordan skulle de så kunne beskæftige sig med dem?

\section{"Familiemøde": en lytning}

Nu er denne opsats' ophavsmand lykkeligvis kommet i berøring med Skammens 
knude af kompleks betydningsdannelse, Skammens Vogns værker binder.

Et uoverskueligt antal strukturer - som alle bidrager til det samlede udtryk og dermed til betydningsdannelsen - er til stede i ethvert musiknummer med sangtekst. Naturligvis er ikke alle lige væsentlige, og analytikeren må fra værk til værk foretage en vurdering af, hvad det er værd at hæfte sig særligt ved. En grov grundinddeling kunne lyde:

i. Den lange række af sproglige strukturer på både et (a) formelt (fx gentagelsesmønstre, rim, rytme osv.) og et (b) indholdsmæssigt niveau.

ii. Den akustiske artikulation heraf, dvs. (a) fremførelsen (herunder fx melodilinjen, fraseringer, agogik (tempovariationer), dynamik (lydstyrkevariationer) - men også (b) stemmens art: dens kvalitet, dvs. klang (herunder nasalitet og evt. fonasteni), timbre, artikulationsgraden, intensiteten (herunder kompression) osv.).

iii. (a) Den lange række af musikalske strukturer og egenskaber (gentagelsesmønstre, melodier, harmonier, tempi, dynamik osv. - men også (b) instrumentering: hvilke lyde er til stede?).

iv. Lydbilledets/produktionens egenskaber (stereopanorering, equalisering, rumklangs-, ekko- og distortioneffekter, mastering osv.).

v. Alle elementerne uden for sangenes akustiske rum, som rækker ind i dette, og som disse rækker ud i: teksternes fremtræden i plade/cd-cover/booklet (typografi, størrelse, linjeombrydning, grafisk opsætning, farver osv.), billedmateriale på og i plade/cd-cover/booklet, forskelligt materiale tilgængeligt på internettet, fx på en gruppes hjemmeside, øvrige værker, liveoptrædener etc.

vi. Det sidste, men væsentligste, forhold er selvfølgelig den måde, disse mange strukturer og egenskaber korresponderer med hinanden - i dette tilfælde i Skammens Vogns kunstneriske fletværk. Ét eksempel herpå kan statueres af sangen "Familiemøde" fra albummet Skammens Vogn; den kan høres på YouTube (http:// www.youtube.com/watch?v=x_xB0G0Wh9Q\&feature=youtu.be).

Alene i lydbilledet står indledningsvis et trædeorgel: et ældre instrument, som kun kan give lyd fra sig, hvis organisten konstant pumper luft ind i det med fodpedalerne. Det er således et omstændeligt arbejde at spille på et trædeorgel, det er et besværligt og næsten klodset instrument. Dets lyd er sørgmodig, men dets fornemste kendetegn er måske dette, at trædefunktionen også kan høres: som en rytmisk, men almindeligvis ikke helt regelmæssig, knirken. En praktisk omstændighed, som er hørbar i lydbilledet, og som forlener udtrykket med en støvet og upoleret grundstemning. På orglet spilles indledningsvis to rundgange af dén elegiske figur, som udgør den melodiske akse, hvorom sangen drejer. Så entrerer stemmen, i følgeskab med en bastone fra trædeorglet, lydbilledet - og dens ankomst er tåkrummende falsk og kejtet. Tænkes lydbilledet som et rum med bredde og dybde, kan stemmens fremtonen opfattes som en indtræden heri - og således som at komme forkert eller kejtet ind ad døren til et selskab, fx et familiemøde. Stemmen er spinkel, svagelig og nasal; den synes ikke at kunne finde den rette tone, men artikulerer famlende ordet "FAMILIEMøDE" (0:08 - således tidsangivelser i det følgende) i en stærkt molpræget tonefølge. Dette indvirker direkte på ordets betydning, det fyldes med famlen og mol, og familiemødet opfattes omgående som en alvorlig, ubehagelig og måske næ- 
sten uhyggelig begivenhed. At "DER ER LAVET TE" (0:21), som det næste udsagn lyder, hjælper ikke det mindste på stemningen - fordi det synges på samme måde, og fordi det er placeret i disse musikalske omgivelser. "Den modernistiske digtning søger at transcendere sproget i retning af dets grænser og orienterer sig i den forstand mod musik", slår kulturteoretikeren Birgitte Stougaard Pedersen fast $(2004,18)$. Overført til sangtekstens område kan det hævdes, at eksempelvis Under Byens forsanger Henriette Sennenvaldt, både i sit ordvalg, i stemmens kvalitet og i kraft af sin sangteknik forvandler den menneskelige stemme til et instrument på næsten lige vilkår med de øvrige instrumenter i lydbilledet. Det diametralt modsatte gør sig gældende hos Zeuthen: Hverken i sin formning af sproget, i stemmekvaliteten eller i sit foredrag bevæger Zeuthen sig i musikkens retning. Stemmen og sproget, og således mennesket, er derimod fremmedgjort i lydbilledet, et kejtet fremmedlegeme, som ikke kan finde sig til rette, men forgæves forsøger på det. Foruden den zeuthenske stemmeføring hænger dette også sammen med den lydtekniske vokalbehandling: Stemmen står næsten uberørt i lydbilledet, uproduceret, uden rumklang, ekko eller andre dybde-, bredde- og skønhedsskabende effekter - naturalistisk, så at sige. Stemmen, mennesket, er hele tiden lidt ved siden af, og dette er af stor vigtighed: Der er en overensstemmelse mellem den måde, jeget er situeret i verden, i livet, og den måde, stemmen er situeret i musikken, i lydlandskabet. Jeget er netop også hele tiden lidt ved siden af tilværelsen og dens tildragelser - som når det i "Sommer igen" fra Bilerne kører ser en studentervogn med unge mennesker: "JEG HøRER IKKE LANGERE TIL DEM | HVIS JEG PRøVEDE AT RÅBE SOM DE GøR | VILLE JEG VIRKE SOM EN KLOVN”. Heller ikke i "Familiemøde" undslipper jeget denne væren-ved-siden-af.

\section{A f $s$ t a $n$ d e}

Efter "DER ER LAVET TE" følger en passage med, hvad man kunne kalde et akustisk enjambement: "OG MAN TALER LIDT" synger stemmen, hvilket i første ombæring synes ganske harmløst - trods alt kan man dog samtale lidt ved det ellers lidet opløftende arrangement. I anden ombæring, dvs. under fortsat lytning, viser det modsatte sig at være tilfældet: 4 sekunder efter følger nemlig den syntaktiske fortsættelse: "FORBI HINANDEN". Som det visuelt perciperbare brud på verslinjen, der er det skriftlige enjambements værktøj, indføjes her i lyden et mellemrum, en pause, i hvilken den grumme flertydighed kan spire.

Man taler lidt forbi hinanden - på samme måde som stemmen og instrumenterne kan siges at tale lidt forbi hinanden: en problemfyldthed i kommunikationen på både et formelt-musikalsk og tematisk-sprogligt niveau. Man når ikke rigtigt hinanden, der er en afstand mellem stemmen og musikken, mellem sætningsdelene og mellem familiemedlemmerne. Det er et grundmotiv hos Zeuthen, og det kommer måske klarest til udtryk i panelet fra tegneserien "Monsieur Rubans meditationer", der er gengivet på side 90. Under tegningen af en mand og en kvinde, adskilt af stiplede linjer, lyder teksten: "På grund af høje, usynlige murværker kan mennesker aldrig helt komme til at mærke hinanden". "DE GÅR SÅ TÆT FORBI HINANDEN", hedder det i sangen "Bilerne kører" fra albummet af samme navn. Og i samme tekst: "[MENNESKENE] BOR INDE BAG VINDUERNE [...] SÅ JEG LøFTER HÅNDEN OP I VEJRET | OG VINKER DET BEDSTE 
JEG HAR LÆRT | JEG VED IKKE HVORFOR JEG GøR DET | MEN AT VINKE ER JO IKKE SÆRLIG SVÆRT". En næsten desperat gestus, et fors $ø$ g på at gennembryde de usynlige murværker, på at række ud og etablere en form for mellemmenneskelig kontakt.

Afstandene findes også mellem ægtefolk: tegneserien "Eriks dag" slutter med Erik Bak Dalgaard - 'Far' i dramaet Voksenfest - liggende i sengen ved sin kone Annes side. "Senere prøver jeg at gøre det godt igen" (2010, 34), lyder det, mens han nærmer sig Anne ved at lægge armen om hende. "God nat, Erik", siger hun (sic, ibid.). Og afstandene findes mellem venner: I tegneserien "Frokost-buffet" er Niels og Helle på frokostbesøg hos René og Alice. "Man tager bare lidt på sin tallerken og sætter sig hvor man vil", bekendtgør René, men det viser sig, at "Niels har svært ved at sidde med tallerknen på sine lår", hvorfor han i stedet sætter sig ved spisebordet $-i$ den anden ende af stuen end det øvrige selskab (se nedenfor). I Voksenfest er det, som i "Familiemøde", afstandene mellem familiemedlemmer (her mellem forældrene og datteren Marie), det drejer sig om: "Det her med de afstande der kan være mellem os. Det her med at nå ind til hinanden. Det her med at nå ind til Marie og turde tage fat på det svære", fortæller Erik Anne $(2012,13)$. "Man kan ikke se hinandens tanker. Man har ikke den samme krop", responderer Anne.

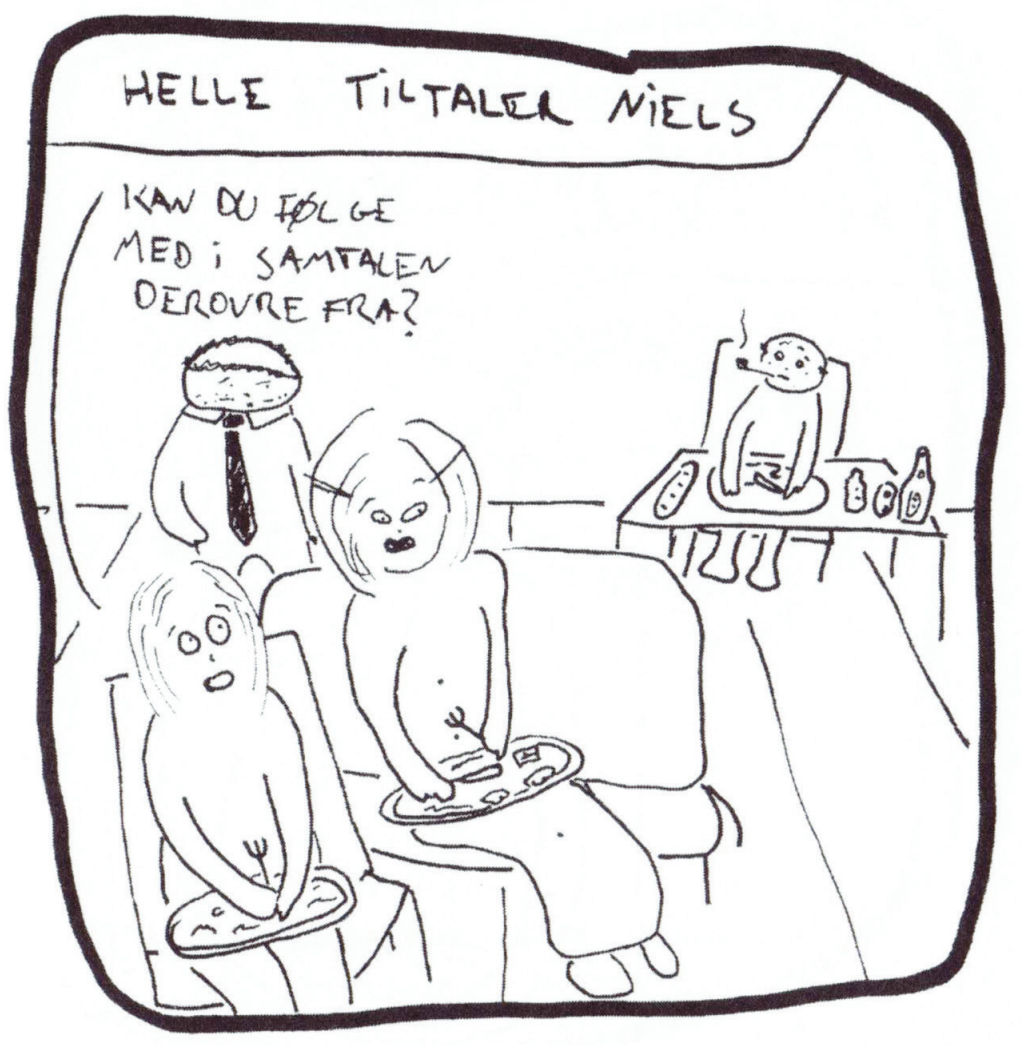




\section{Det sungne \& måden hvorpå}

I familiemødet var man i færd med at tale "FORBI HINANDEN", nu kæmper trædeorglet møjsommeligt videre. “OG SPISER EN BOLLE” lyder det så. Med 'bolle’ bevæger melodien sig nedefter, dernæst en lille pause, som øger forventningen om det kommende. På et musikalsk niveau indfries denne forventning til fulde umiddelbart efter: I højre side af lydbilledet slutter en andenstemme sig til og stiger hånd i hånd med melodistemmen højere og højere op, intenst og inderligt (0:52). Imidlertid kan det bløde, hvide fænomen, der artikuleres under denne tostemmige opstigen, samt den danske lydfigur, der henviser hertil, meget vanskeligt bære denne melodiøse skøn- og storladenhed: "MED SMørEOsT". Det sungne er spændt ud mod måden, det synges på, og denne udspændthed, som forbinder det høje med det lave, virker morsom - eller måske snarere tragikomisk. Smøreostens betydningspotentiale udvides betydeligt, den får gennem den melodiske, tostemmige frasering og stemmernes fragile beskaffenhed en nærmest symbolsk karakter, bliver et sørgeligt sindbillede på familiemødet. Konstruktionen indebærer altså på den ene side, at harmonierne, melodierne, instrumenteringen, stemmeføringen og stemmekvaliteten fundamentalt modsvarer den ubehagelige og pinlige stemning, som teksten indholdsmæssigt beskriver, på den anden side etableres samtidig et kontrastfyldt forhold mellem musik og tekst. Når det i en anmeldelse hedder, at "tekst og musik indgår [...] en hidtil uhørt velfungerende pagt" (Kristensen 2008) hos Skammens Vogn, hænger det sammen med dette, for disse komplekse strukturer indfanger nogle sammensatte og subtile, men meget genkendelige, menneskelige følelser og erfaringer.

Efter dette i smøreost indsmurte crescendo indfinder et lille lydhul sig (0:57): også på dette niveau findes afstandene. Så sætter orglet i gang med den repetitive figur, som løber gennem hele nummeret og fremelsker den knugende stilstandsfornemmelse. Stemmen igen: "FOR EKSEMPEL SIGER FAR | AT HAN KRÆVER SIN RET". Denne mand, som kræver sin ret, er en type, der optræder flere steder hos Zeuthen, $\mathrm{fx}$ digtet "Fars sande standpunkt": "far ved at han er en mand / med en mands begær og lyst til nydelse / og han ved at det er hans gode ret at leve / som denne mand" $(2009,51)$. Og i Voksenfest forklarer Erik Bak Dalgaard, Far, sin kone og datter: "Altså, jeg er p.t. meget optaget af hvad jeg kan gøre for at kræve min ret i huset" (2012, 14). Opførslen kan opfattes som en reaktion mod den slaphed, der præger de jeg-skikkelser, der er fremherskende hos Zeuthen: disse skrøbelige, sørgmodige, selvhadske unge mænd med vigende mandighed - i det fiktive filmreferat "Humanist" står han i 3. person og hedder Gregers: "Han har mistet lidt af sin mandighed, siger hun" $(2009,59)$, Gregers kæreste, idet hun forlader ham. (p. 51). Et sted hos Skammens Vogn hedder han Martin og står i 1. person: "MINE DRøMME OG ØNSKER ER GANSKE SMÅ | MEN JEG SKAMMER MIG | JEG FØLER LIDT SKYLD TIL DE FLESTE | JEG STRAFFER MIG SELV FOR DET MESTE | JEG HEDDER MARTIN" ("Martin", Skammens Vogn). Måske hedder han også undertiden Nikolaj Zeuthen, men uanset navnet er han en dansk mand omkring de tredive i det 21. århundrede, som ikke har det let - som er et almindeligt, fejlbarligt menneske. 


\section{Det ffejlbarlige mennekse}

Som tidligere strejfet tematiseres fejlbarligheden hos Zeuthen ikke blot, den praktiseres også. To anmeldere hos det indflydelsesrige musikmagasin Gaffa anskuer den zeuthenske sangteknik på følgende måde: "Zeuthen synger ganske forfærdeligt, og selvom man ikke behøver at synge som C-Lo Green, kan man sagtens have udtrykket i orden. [...] det kan på ingen måde forsvares, at Zeuthen lyder som en uinspireret Jodle Kjeld og dermed spolerer den aldeles anstændige musikalitet, bandet lægger for døren [sic]" (Rosenstand-Svidt \& Gonzalez 2008). Anmelderne sætter dermed orden, inspirerethed og anstændighed som efterstræbelsesværdige størrelser, mens dette at synge ganske forfærdeligt sættes som en absolut negativ egenskab. Frem for at forsøge at begribe, hvilken betydningsdannelse sangerens uinspirerethed, uanstændighed og uordentlighed i udtrykket tilvejebringer (om ikke andet kunne hans øvrige værk tilskynde til en sådan åben- og tålmodighed), arbejder de to anmeldere med en æstetisk barre, som efter alt at dømme kan sammenlignes med en atletikudøvers kvalitetsmålestok: At synge godt vil sige at være god til at synge; at være i stand til at beherske det menneskelige vokalinstrument på en teknisk overlegen måde, altså omtrent svarende til at kunne løbe hurtigt, springe højt, kaste langt etc. - med andre ord: den rent håndværksmæssige kunnen. Imidlertid lader kunstneriske frembringelsers kvalitet sig som bekendt ikke afgøre på en helt så simpel måde: De store punkorkestres værker bliver eksempelvis ikke dårligere, fordi musikerne evt. ikke i traditionel forstand er teknisk dygtige til at håndtere deres instrumenter. På samme måde tegner Nikolaj Zeuthen også 'dårligt', uden at det mindsker tegneseriernes værdi: De er udtryksfulde, intelligente og tankevækkende. Karakteristisk spørger litteraturmagasinet Senturas anmelder Christian Bonde Korsgaard sig selv, "hvor godt det kunne være blevet med en bedre tegner. Måske var det blevet dårligere?" (2010). Det samme gælder Zeuthens vokale udgydelser: Det er 'dårligt', men på en 'god' måde - dvs. på en, i forhold til det samlede kunstneriske projekt, vellykket og interessant måde. Og det er velovervejet: Vil man (med diktummet om den intentionelle fejlslutning in mente) forvisse sig om ophavsmændenes pertentlighed i omgangen med stoffet og seriøsitet omkring foretagenet, kan man lægge øre til Zeuthen, når han beretter om, hvordan "[a]lle tre medlemmer i Skammens Vogn tager bandet og hver eneste sang dybt seriøst, og vi tænker over og diskuterer betydningen af vores udtryk i én uendelighed. Skammens Vogn er måske ikke et højtideligt orkester, men vi tager det, vi laver, gravalvorligt" (Christiansen 2010, 68). I sidste ende er hovedsagen, at det honoreres at lytte opmærksomt og grundigt til denne tvivlsomme og tvivlende sangstemme.

Det fejlbarlige fungerer hos Zeuthen som en frugtbar og konsekvent gennemført æstetisk strategi, ved hjælp af hvilken løsninger på kunstneriske problemer, som ikke lader sig løse med eksempelvis ækvilibristisk skønsang, kan findes. Dermed bliver spørgsmålet, om han kunne synge 'bedre', hvis han ønskede det, underordnet. Netop kun ved at synge på denne afmægtige måde, netop kun ved ikke at demonstrere sangteknisk overlegenhed, kan den usikre mandeskikkelse, som i forskellige former behandles på tværs af œuvret, opføres, praktiseres. Den vokale afmagt over for de musikalske udfordringer svarer til den menneskelige afmagt over for tilværelsens. Informations musikanmelder Ralf Christensen karakteriserer træffende 


\section{BAK DalgaAnd}
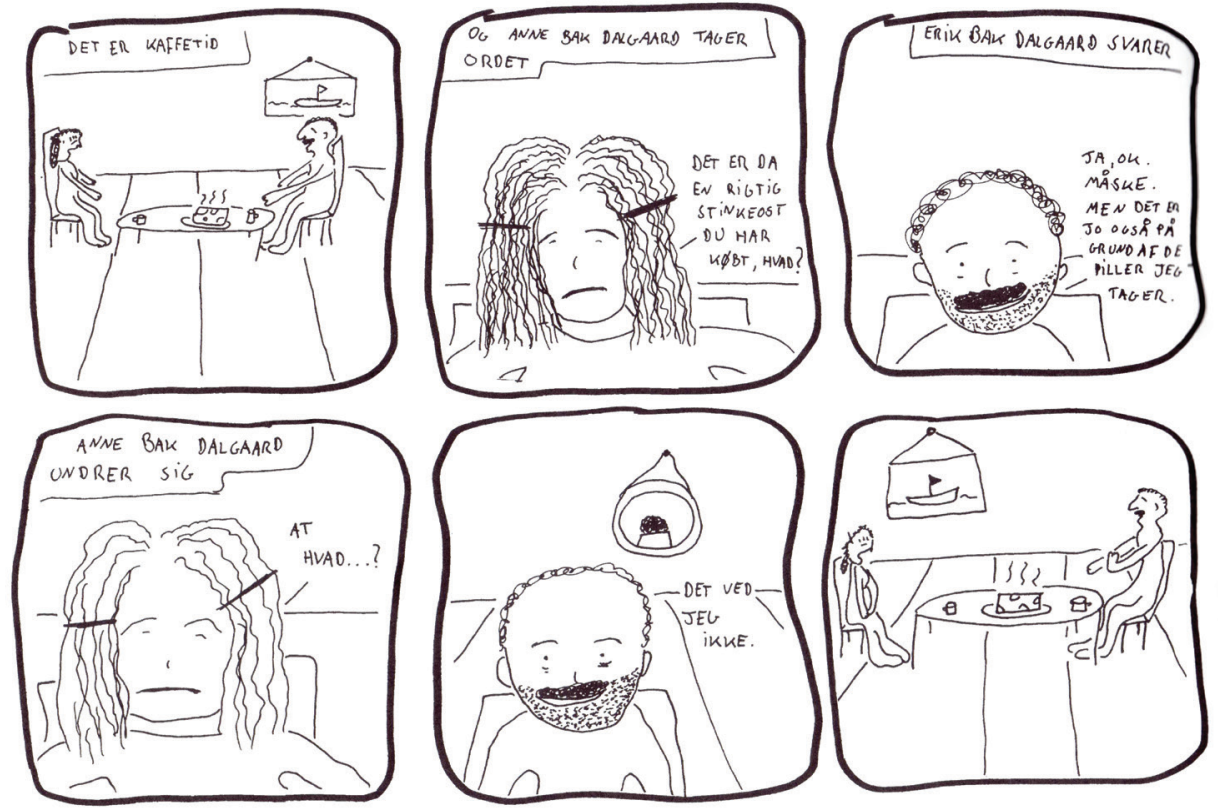

Zeuthen som "noget af en ikkesanger", men fortsætter: "uden at [han] på noget tidspunkt bliver uvedkommende eller selvudslettende. Og der er en finurligt formuleret følsomhed i hans fraseringer, en intelligent behandlet, aldrig køligt camoufleret sårbarhed" (2008). Hos musikmagasinet Geiger hedder det tilsvarende om albummet Skammens Vogn, at dets "helt store force [...] imidlertid [er] Zeuthen. Manden kan ikke synge - lad så meget stå helt fast - og gør ikke det store for at skjule det. Der både lalles, brummes og køres op i registre, han godt selv ved, at han ikke behersker. Men han har lige netop den meget særegne personlige touch, der skal til for at få hans ikke helt ordinære tekster til at leve" (Pedersen 2007).

Dette "særegne personlige touch" er i høj grad netop knyttet til fejlbarligheden og denne kommer til udtryk på talrige måder: som musikalske fejl (fx umotiverede klik i lydbilledet), som sangfejl (fx kommer vokalen undertiden for sent ind eller er simpelthen udpræget falsk), som stavefejl (fx optræder i en tegneserie et "sindrigt arrangemet" $(2010,17)$ ) og skrivefejl (fx er i en tegneserie ordet 'om' streget ud i et billede til fordel for ordet 'at' $(2010,38))$. Dertil kommer træk, der vanskeligt kan kaldes udprægede fejl, men som er beslægtede med fejlen - som når det fra Zeuthen lyder: “JA, HVAD GIVER DU”, og han udtaler v'et distinkt (vendingen eksisterer egentlig kun som det mundtlige udbrud: hvad gir du!?), eller som når baggrundene bag tegneseriepersonerne ændrer sig fra billede til billede: Så hænger der et skibsmaleri på bagvæggen, så gør der ikke, så står der pludselig en plante i stuen osv. (jf. Bak Dalgaards hjem ovenfor). Eller som når sangen "Outro" er nummer 9 ud af 12 på Bilerne kører. Eller som selvfremstillingen på Oliebål-omslaget med grød ud over grydekanten og forfatteren iklædt noget, der kunne være den indledningsvise hjemmebuks: i en uperfekt virkelighed, i en uperfekt verden med mennesker, som ikke kan undgå konstant at geråde i problemer. Fejlbarligheden hænger, som 
det fremgår, sammen med det kejtede og pinlige, det klodsede og flove, som findes overalt: i festsangsagtige, antikverede udtalemåder, fX "SÅ' DET BLEVET SOMMER IGEN" ("Sommer igen", Bilerne kører) med distinkt v-lyd; i ærgerlige, festsangsagtige enderim, fx "JEG SIGER NOGET, DU SIGER NOGET TILBAGE $\mid$ DEN KøRER PING-PONG, INGEN GRUND TIL AT KLAGE" ("Samtalen kører", Bilerne kører) eller i det skrøbelige fors $\varnothing \mathrm{g}$ på falsetsang i "Tak mor" (Skammens Vogn). Det er der, når man er "MED MOR I CIRKUs" og "HUN HAR кØвт EN ALT FOR DYR BILLET" (samme sang) og når man får gaver, man ikke bliver glad for ("Knud og Bodil", Bilerne kører). Det er der, når kæresteparret Rune og Anna i Verdensmestre under et restaurantbesøg i Sydspanien må sande, at menukortets "'home made sauce' var opvarmet fløde og 'special herbs' nogle tørrede, udtjente urter" $(2010,81)$. Det lurer i mangfoldigheden af uskønne almindeligheder som varmeapparater, klapvogne, regnbukser - gennemtræk, ribbenssteg og korte, kolde tissemænd. Og apropos tissemænd er det der i dén grad, når i Voksenfest Far, under en art selvopfundet konfirmationsritual, kaster sig ned for fødderne af sin teenagedatter for knælende at kysse "en trist påsyet tissemand" på en "temmelig frastødende hudfarvet heldragt med hætte", hun modvilligt er blevet tvunget ind i (2012, 33). Den opbyggelige pointe lyder nu, at selvhadet og mindreværdskomplekserne, skammen og pinligheden, alle de knugende, ubehagelige følelser, gennem værkerne kan italesættes - og ved humorens hjælp udholdes: "Humoren kan jo være en vej ind til noget alvorligt, eller en måde at håndtere noget alvorligt, intimt og tabubelagt. Eller skamfuldt" (Christiansen 2010, 68), som Zeuthen selv udtrykker sig i et interview.

\section{Sjov \& psykologi}

Og så tilbage til familiemødet og far, som kræver sin ret. "DET ER PÅ EN MÅDE | MENT I sJov", kommenteres hans forlangende efterfølgende. Men denne kommentar er ikke kun syntaktisk-semantisk gestaltet, også musikalsk og sangteknisk: Ved "EN MÅDE" (1:22) famler stemmen efter tonerne, rammer dem ikke helt og fremstår fortabt. Artikuleret med så påfaldende en mangel på fyndighed, synes det som om, stemmen ikke rigtigt stoler på det, den selv synger - som om den ikke rigtigt har lyst til at synge det. Dernæst stiger melodien opad på "MENT I" - for så at falde dybt ned og lande tungt på en mol-akkord med "sJov". Mol-dysterheden og den tonale bevægelse nedad står i skærende kontrast til ordet 'sjov': igen er den musikalske form og det sproglige indhold udspændt mod hinanden. Om komponisten Thomas Laubs mere kølige melodi (end C. Chr. Hoffmans populære romantiske) til Grundtvig-salmen "Hil dig, Frelser og Forsoner!" hedder det hos kirkehistorikeren Jørgen I. Jensen, at "melodien betegner et kontrastpunkt til teksten, således at der bliver yderligere rum omkring det, der siges" (Jensen 2004, 75). Den tidslige og kulturelle kløft lader sig her problemfrit overspringe på et strukturelt plan og Jensen-citatet sig overføre direkte til passagen i "Familiemøde", hvor der skabes et alvorsfuldt rum omkring den morskab, der omtales. Passagen kan stå som et billede ikke blot på "Familiemøde" som værk, men på hele Zeuthens virke: Det er på en måde (nemlig på en alvorlig måde) ment i sjov. Skamløst skamfuld humor for alvor.

\footnotetext{
"HAN RYGER PÅ EN CIGARET", lyder det efterfølgende om Far. Denne rygen genfindes i
} 
"Fars sande standpunkt", hvor "[far] elsker at provokere konen ved at gå udenfor og ryge cigaretter" (p. 50). Ægtemanden og familiefaderen, der klamrer sig til en skrøbelig maskulinitet, kræver sin ret. Heroverfor står hustruen, som også er moderen - svarende til Mor, som den sidste del af teksten i "Familiemøde" handler om: "MOR HAR LAST EN BOG | DEN HANDLER OM". Som det var tilfældet med smøreosten, bygges vha. pausering før det kommende ord en spænding op: ca. 4 sekunder går der efter "om", før en voldsom forløsning finder sted. Sekvensen stiger og stiger i både volumen og tone, og tempoet spændes i en bue; der tages tilløb til det afslutningsvise ord, som synes aldrig at ville høre op: "PSYKOLOGI" (2:13). Denne kulmination er næsten uudholdelig, dirrende af dramatisk sjælelig vånde, svøbt i galgenhumor. Begrebet 'psykologi', som her, musikalsk og vokalt, fyldes til bristepunktet med emotionel betydning, står helt centralt i Zeuthens arbejde: På allerførste side i romanen Verdensmestre hedder det: "den iver hvormed man overalt tog fat i 'det psykologiske" $(2010,6)$. På forsiden af tegneserien Hvad synes du om dansk litteratur? konstaterer figuren René med armene på ryggen: "Det er psykologi det hele", og i tegneserien "Programmet" ser selvsamme René - sammen med sin kone Alice og vennerne Niels og Helle - en fjernsynsudsendelse, der, præcis som Mors bog, "handler om psykologi". Dr. Anders i Voksenfest er Fars psykolog, og foretager gennem hele stykket psykologiske analyser af udsagn og begivenheder. Og i nummeret "Psykolog" tages emnet ikke overraskende også op: "TIL PSYKOLOGI | TIL PSYKOLOGI | JEG VED IKKE | OM DET HJÆLPER NOGET | HJELLPER NOGET". Imidlertid står det mindre klart, hvilken rolle psykologien egentlig spiller. Den bliver til en underligt tom og uforpligtende glose, plukket ud af samtidens offentlige diskurs. 'Psykologien', og en måde at omtale den på, et sprog, et tonefald, udstilles og fremstår i denne position tragikomisk: uanset hvor meget "det psykologiske" eksplicit omtales, synes de mennesker, der befolker de zeuthenske universer, ikke at blive klogere på psyken - i hvert fald ikke på en sådan måde, at det mellemmenneskelige samvær lettes. Også i Voksenfest holdes familiemøde (i 2. akt, 2. scene), og Far forklarer for sin datter og hustru: "Sammen har vi det man kalder en relation. Os alle tre imellem. En menneskelig relation. Vi er ikke robotter, hvis man kan sige det på den måde" (2012, 18f.) - ikke robotter, men fejlbarlige mennesker, hvis man kan sige det på den måde.

Familiemødet nærmer sig nu sin afslutning. På den hjerteskærende psykologiske kulmination følger et kort mellemspil. Her dukker langsomt en lys synthesizer frem (2:24), skælvende med tremolo. Det synes som om, den overtager stemmens plads, blot talende et ikke-referentielt sprog, ${ }^{4}$ et følelsernes sprog, som - inden for værkets rammer - er meget præcist. Det synes indlysende, at det er familiemødet, synthesizeren fortæller om; melankolsk, men også tindrende, glimtende, med en lindrende finhed i forhold til den dumpe og tunge orgelsump. Vel instrumentalt! "HUN RøRER VED MIN ARM" (2:52) lyder en sidste løsrevet replik, det er ikke nødvendigt at sige mere: Handlingen i sig selv siger det hele. Efter de sidste ord i "Familiemøde" sætter et længere instrumentalt efterspil ind. Det bliver et resonansrum, i hvilket hændelserne, følelserne og tankerne kan klinge ud og bundfælde sig. Nye musikalske figurer, der ikke har optrådt tidligere, fletter sig dulmende ind i monotonien som lysstråler (3:10) og foreslår med synthesizerens milde rislen, at det hele nok skal gå alligevel: Mødet er hævet. 


\section{Udkørsel}

Modsat eksempelvis Shu-bi-dua indtager Nikolaj Zeuthen og Skammens Vogn ikke en "central plads i moderne dansk populærkultur" (Farø \& Lorentzen 2008, 6). En undersøgelse som denne kan således, modsat Farø \& Lorentzens af Shu-bi-dua, ikke søge sin legitimitet i kvantitative, samfundsmæssige forhold. I stedet kan den gøre som Charles Bernstein, når han i indledningen til antologien Close Listening, der tidligere citeredes fra, forklarer, hvordan den "særligt retter opmærksomheden mod innovativt arbejde" $(1998,3)$. Netop dette har også været udgangspunktet her: Zeuthens arbejde er "innovativt", han skriver og fremfører dansk lyrik på originale og interessante måder, som fortjener videnskabelig opmærksomhed - men som, bl.a. af de beskrevne mediale, institutionelle og kulturelle årsager, hidtil er blevet forbigået på det, ja, skammeligste. Under gennemgangen af "Familiemøde" fremgik det, at disse originale og interessante måder ofte kan forbindes med begrebet 'fejlbarlighed', og hvad deraf følger: en vognladning af knugende følelser. Zeuthen arbejder ikke ud fra en rosenkranzsk Ästhetik des Häßlichen, men etablerer i stedet en kejtethedens og klodsethedens, en pinlighedens og flovhedens æstetik, idet han både tematiserer og praktiserer det ikke-overbevisende og mislykkede, det mangelfulde og fejlbarlige.

\section{Noter}

I Zeuthens sangtekster findes udelukkende på tryk på pladecoverne, og det er disse, der danner forlæg for de anvendte citater. Således også på bogstavniveau: Da sangteksterne er sat i kapitæler, citeres de også sådan; (typo-)grafisk fejlcitering kan i kunstnerisk sammenhæng betragtes som næsten lige så lidt ønskelig som ortografisk: Begge dele betyder noget. Endvidere: Det fremgår af et interview, at det for Zeuthen er magtpåliggende ikke at trykke sangteksterne som digte $i$ en digtsamling, at sang og digt "udgør to helt forskellige sfærer" (Christiansen 2010, 69). I forlængelse af ovenstående må det således bemærkes, at tekster sat i kapitæler for digtsamlingers vedkommende hører til kuriositeterne, mens det for pladecovers og bookletters vedkommende tenderer mod det gængse. En mulig forklaring kunne være, at kapitælerne i deres (højdemæssige) ensartethed rummer en grad af neutralitet, hvorved de skriftlige tekstversioner kan sættes til at spille en anden rolle end 'digtet': at komme lytteren til hjælp i eventuelle under lytningen forekommende tvivlstilfælde - og dermed ikke denne: at være selvstændige, æstetisk markante sprogkunstværker. Det er lyden, det handler om - og dette forehavende er der, skønt stedt i skriftligheden, ingen grund til at intervenere i her. Af samme grund markeres linjebrud med | i stedet for den traditionelle /: for at signalere en forskel til digtet.

2 Der kan heldigvis anføres en række undtagelser (som imidlertid ikke ændrer det store billede), fx Anette Giertsens sangtekstantologi Vinyllyrik og Lars Bukdahls raptekstsamling Poesi dér. Initiativer som Anya Mathilde Poulsens Feminint forstærket og Jens Larsens Sangskriver. Elleve samtaler kan vanskeligt medregnes i denne sammenhæng, da de snarere er musikalsk end litterært funderede. På angelsaksisk grund kan især Charles Bernsteins hhv. Marjorie Perloffs antologier Close Listening og The Sound of Poetry / The Poetry of Sound nævnes som vigtige indspil.

3 Det fortælles om den schweiziske reformator Huldrych Zwingli, at han - da han drog til Zürich for ved et koncilium at overbevise forsamlingen om kirkesangens fortrædeligheder, dens tilbøjelighed til at forskyde de syngende og lyttendes opmærksomhed fra Ordet mod tonerne - frem- 
førte sine synspunkter på en helt særlig måde: syngende.

4 Spørgsmålet om musikkens (eventuelle) referentialitet er omfattende og omdiskuteret; Lars Elleströms udlægning (som knytter sig til hans mediedistinktioner) lyder sådan: "de musikalske tegn er lydlige tegn, der hovedsageligt refererer til bevægelser, følelser, kropslige oplevelser og kognitive strukturer" (2012, 25 vores kursiv) - men i en tilhørende note knytter han kommentaren: "Jeg er klar over manglen på konsensus [...] når det gælder spørgsmålet om betydning i musik" (op.cit., 45). Når vi i teksten kalder musikkens ‘sprog' for "ikke-referentielt” er det således snarere i en jakobsonsk betydning af begrebet (jf. den referentielle funktion som "indhold" eller "information") og ikke i den elleströmske, som måske kan kaldes kognitionsteoretisk.

\section{Litteratur \& musik}

Bernstein, Charles (1998): "Introduction", i Close Listening. Poetry and the Performed Word (red. Charles Bernstein), Oxford: Oxford University Press, s. 3-26.

Bukdahl, Lars (2004): Poesi dér. Danske raptekster 1988-2004, Aarhus: Systime.

Christiansen, Mads K. (2010): "Noget smukt som en slags undskyldning. Et interview med Nikolaj Zeuthen", i Geiger 18, Aarhus, s. 66-71.

Christensen, Ralf (2008): “Afmagt og salmesang” i Dagbladet Information, d. 20/12.

Elleström, Lars (2012): "Mediernes modaliteter. En model til forståelse af intermediale relationer" (oversat af Sara Tanderup) i Birgitte Stougaard Pedersen \& Mette-Marie Zacher Sørensen (red.) Medialitet, intermedialitet og analyse, Akademiet for Æstetikfaglig forskeruddannelse, Aarhus Universitet: Aarhus.

Farø, Ken \& Henrik Lorentzen (2008): “Danmarks logofile orkester: Shu-bi-dua og sproget”, i Jørgensen, Merete K., Henrik Blicher \& Simon Skovgaard Boeck (red.): Danske Studier 103.

Giertsen, Anette (1982) (red.): Vinyllyrik. 227 tekster fra dansk rock- og folkemusik 1967-82, København: Dansklærerforeningen/Skov \& Medley Records.

Jensen, Jørgen I. (2004): Mødepunkter. Teologi-kultur-musik, København: Anis.

Kjørup, Frank (2003): Sprog versus sprog, København: Museum Tusculanum.

Korsgaard, Christian Bonde (2010): "Mellem grin og gru. Verdens måske grimmeste tegneserie", i Sentura, http://www.sentura.dk/zeuthen_anmeldelse.html.

Kristensen, Janne (2008): “Skammens Vogn: ‘s.t.”, anmeldelse, i Undertoner, d. 17/1, http://www. undertoner.dk/2008/01/skammens-vogn-st/.

Larsen, Jens (2001): Sangskriver. Elleve samtaler, København: Lindhardt \& Ringhof.

Moser, Sibylle (2007): "Media modes of poetic reception. Reading lyrics versus listening to songs", i Poetics 35, s. 277-300.

Mygind, Johanne (2009): “Jeg ville hellere være som Dan Turèll, men det kan jeg ikke finde ud af”, i Dagbladet Information, d. 27/3, http://www.information.dk/186262.

Naschert, Guido (2006): "Wider eine halbierte Lyrik. Überlegungen zu den Desideraten und Möglichkeiten eines textwissenschaftlichen Umgangs mit SongPoesi”, i Jahrbuch der ungarischen Germanistik, Budapest, s. 106-118.

Nielsen, Carsten René (1996): "Den utydelige grænse mellem kaos og orden: interview med lyrikeren og encyklopædisten Morten Søndergaard”, i Ildfisken 14, Aarhus, s. 13-21.

Pedersen, Steffen B. (2007): "Skammens Vogn: Skammens Vogn”, i Geiger.dk, d. 12/9, http://www. geiger.dk/anmeldelser/anmeldelse.php?id=2815. 
ningsdannelse i litteratur og musik, upubliceret ph.d.-afhandling, Aarhus (udgivet i bogform som Lyd, litteratur og musik - gestus i kunstoplevelsen i 2008, Aarhus: Aarhus Universitetsforlag).

Poulsen, Anya Mathilde (2007): Feminint forstærket. Syv samtaler med kvindelige musikere, København: DR Multimedie.

Ringgaard, Dan (2000): "De bundne former og avantgarden. Et kunstnerisk alternativ til at gå i ét med tiden, er at gå i rette med den”, i Standart 14.1, Aarhus, s. 25-26.

Schweppenhäuser, Jakob (2011): "Det usynlige menneske. Om PeterLichts interdisciplinære antipop-pop", i Den Blå Port 87, s. 41-53.

Skammens Vogn, (2007): Live-set at Liz Berg's show @ WFMU (internetudgivelse).

Skammens Vogn (2007): Skammens Vogn, Lolita Industri.

Skammens Vogn (2008): Bilerne kører, Lolita Industri.

Svidt, Ole Rosenstand \& Michael Jose Gonzalez (2008): "Skammens Vogn: ‘Bilerne kører”, anmeldelse, i Gaffa, d. 3/11, http://gaffa.dk/anmeldelse/29684.

Søndergaard, Rune (2008): “Pop, ræb og rap - nu i A5!” i Vandfanget 45, s. 4.

Sørensen, Rasmus Bo (2009): "Danske digtere sprænger lydmuren”, i Dagbladet Information d. 29/1. Zeuthen, Nikolaj (2006): "Kunst og ambition", i Det spekulative øre (red.: Torben Sangild), d. 21/10, blog, http://www.groveloejer.dk/detspekulativeoere/2006/10/kunst_og_ambition_v_nikolaj_ze.html).

Zeuthen, Nikolaj (2007): "Kunst er høflighed", i Dagbladet Information d. 25/6, http://www.information.dk/118206.

Zeuthen, Nikolaj (2009): Oliebål, København: Samleren.

Zeuthen, Nikolaj (2012): Frivers fra Howitzvej, København: Samleren.

Zeuthen, Nikolaj (2010): Hvad synes du om dansk litteratur?, Aarhus: Comics After Hand (Edition After Hand).

Zeuthen, Nikolaj (2012): Voksenfest, Aarhus: Edition After Hand.

Zeuthen, Nikolaj (2010): Verdensmestre, København: Samleren. 